\title{
Urban Upgrading in a Context of Violence: Perceptions of Security and Physical Space in the Case of the Favela-Bairro in Rio de Janeiro
}

\author{
Jota Samper \\ University of Colorado Boulder, Colorado, USA
}

\begin{abstract}
Spaces of informality, such as favelas, barriadas and tugurios are seen by media, municipalities and security institutions as dangerous places. Today municipalities and international agencies use new forms of urban upgrading as tools to address both the traditional structural problems of poverty and also as tools for violence prevention. While a causation between informal spaces and insecurity clearly does not exist, there is an interest in understanding the influence of physical interventions in neighborhood security behavior. This research tests ways in which urban projects alter perceptions of security among favela dwellers over time, in the Rio de Janeiro "Favela-Bairro" urban upgrading project. Finds that while security conditions are marginally affected, location close to main roads part of the urban upgrading project affect residents' security perceptions positively. However, individuals in less accessible areas of the favela present less openness to address security questions. It argues that individual proximity to upgraded main roads experience shelter from the effects of retaliation from perverse actors than those that have their accessibility impeded. Other projects such as public spaces or buildings show no significative changes in security perceptions.
\end{abstract}

Keywords: informal settlements, urban conflict, planning, physical space, favelas

\section{Introduction: Using Urban Upgrading of Informal Settlements as a Security Strategy}

Today in Latin American cities the names of areas with presence of informal settlements are synonymous with areas controlled by illegal armed groups. Neighborhoods like Comuna 13 in Medellin, Petare in Caracas or Rocinha in Rio de Janeiro are prototypical examples of this relationship. A spatial causation for conflict has been all discredited by social sciences (J. R. Blau \& P. M. Blau, 1982). However, there is an agreement that populations that live in these areas suffer most the effects of violence from armed groups outside of the rule of law (Arias, 2006; Zaluar \& Alvito, 1998; Zaluar, 2004). As far back as with Haussmann urban intervention in Paris, a connection exists between modifying urban physical space as a way to increase security in cities (Graham, 2012; Jordan, 1995). Security urban practices dwell on the idea that the level of maintenance of public space have impacts in the way disorder and criminality happen in public space (Newman, 1972; Wilson $\&$ Kelling, 1982). Furthermore, the design of urban spaces that promote a constant active urban environment and surveillance of public space, or "eyes on the street", increase levels of security (Jacobs, 1961). In the "global south", military practices emphasize modifying urban environments dominated by non-state actors as

Jota Samper, Ph.D., Program in Environmental Design, University of Colorado Boulder. 
ways to increase the leverage of state security practices. The case of the Israel-Palestinian conflict illustrates this idea, here Ariel Sharon used opening streets in Palestinian settlements for the movement of Israeli troops as a strategic military move (Weizman, 2006). These examples suggest that changing the urban form of these places can provide better security.

In Latin America, the spatial intersection of security policies and poverty alleviation policies in the places of poverty has led municipalities to claim that urban upgrading projects are both tools to alleviate poverty conditions and to increase security (Samper, 2012). Eduardo Rojas finds a "trend" in Latin American neighborhood upgrading programs, in which, they are used as tools for "protecting vulnerable groups (such as young people at risk) and decreasing urban violence" (Rojas, Inter-American Development Bank, \& Cities Alliance, 2010). Key in such assertion is the idea that physical space plays a fundamental role in the quality of life of such communities as well as how armed actors wage war. There is still disagreement on the role of urban interventions on security, some agree that "interventions in neighborhood physical infrastructure can reduce violence" (Cerdá et al., 2012), while others contend that communities' perceived sense of security differs from actual measured safety (López \& Lukinbeal, 2010). Inside this tension between the real and perceived effects on security of urban upgrading projects, there is a research project question: In which ways urban upgrading projects in poor, violent neighborhoods change the perception of security of community members in these areas? Moreover, if any changes are perceived, what are the key physical interventions that contribute to increases (or decreases) in the perception of security?

This paper explores the intersection of those concepts in what Elizabeth Riley et al. calls "the new generation of urban upgrading programs in Latin American cities" (2001) as a fundamental way that (policy and physical) interventions in informal settlements can affect the residents' quality of life and perceptions of security. It maps the effects of those projects in the oldest and most renowned urban upgrading project in Latin America, the Favela-Bairro (FB) project. To answer the research question a "multi-method" approach is used (Teddlie \& Tashakkori, 2003), that combines semi-structured interviews with planners and community members, as well as georeferencing mapping of perceptions of security in three favelas. This research finds that general conditions of conflict had not changed and in most cases have worsened in the city of Rio de Janeiro from the time of the project implementation to the present.

Residents agree the projects have positively improved their quality of life. Residents consider that the most salient element of urban upgrading regarding the quality of life is the widening and paving of roads. No consensus exists if projects improved conditions of security over the years. Some see these as opening their neighborhoods to violent external actors, and others see their value as making spaces more attractive for further development and to positive external actors. The mapping of security responses shows that residents in proximity to key transportations roads present a higher level of willingness to express views about security. The intersection of interviews and mapping confirms the value of the mobility infrastructure as a key element in the changing of perceptions of security. It also presents evidence that suggests the mix of foreign and local individuals in the main roads (spine) of these informal settlements are the result of urban upgrading providing an environment in which community members' anonymity protect them from the surveillance and repression of the criminal groups that exert violence in these spaces.

The following section presents the research methodology, followed by an overview of the process urban upgrading in Latin America and its intersection with issues of security. Next section introduces the case of the Favela Barrio Project in Rio de Janeiro and its three embedded favelas, and how this case illustrates the effects 
of upgrading on favela security. Ending with a section that presents the findings and reflection on its implications and future research.

\section{Methodology, Measuring Physical Space Change and Safety Perceptions in Three Favelas}

This research focuses on perceptions using two methodological approaches to recognize the relationship between the physical changes introduced by urban upgrading projects in favelas with levels of violent conflict and how they affected perceptions of security. This project uses a "multi-method" (Teddlie \& Tashakkori, 2003), with two types of qualitative research methods, firsr, a comparative analysis of semi-structured interviews with the implementers of the projects and community members, followed by, second, a mapping of perceptions of security values across project areas based on analysis of the semi-structured interviews with community members. The research is interested in understanding if there is any relationship between perceptions of security and other changes in the neighborhood context (spatial, political, policy, participatory or economical), as observed by the residents. Moreover, seek to understand if these changes are indeed the ones performed by the FB project, or not. The research focuses on perceptions for two main reasons: first, it is not clear that the reduction in homicide rates in Rio (from 78 homicides per 100,000 inhabitants in 1994 to 50 in 2008) is a result of policies of urban upgrading; second, as in the case of upgrading and security in Medellin (Samper Escobar, 2010), fluctuation of homicide rates does not necessarily match perceptions at the neighborhood level. Janice Perlman's horizontal study of favelas in Rio de Janeiro concludes that in the present, community members are more concerned about issues of security than they were at the time of her first sampling (Perlman, 2010) of pre-urban upgrading. This finding contradicts the story that homicide rates portrait as presenting the city and favelas as less violent over time.

The Favela-Bairro (FB) project as a case study is important because it is the first of its kind, and a case well regarded in the literature of urban upgrading as a best practice. Since 1994 to the present this project has been implemented in 148 favelas and is one of the largest slum-upgrading programs implemented to date in Latin America (Riley, 2001). The three favelas selected as embedded units (favelas) were chosen because these are considered the poster children of success in terms of fulfilling the FB project goals (Conde \& Magalhães, 2004; Duarte, Silva, \& Brasileiro, 1996). Also, they present incidence of illegal armed groups. These cases are then an example of what Robert K. Yin called a "representative or typical" case: "The lessons learned from these cases are assumed to be informative about the average person or institution" (Yin, 2009, p. 48).

Specifically, I map the interventions of the FB, based on empirical data gathered using qualitative methods thru semi-structured interviews in three favelas (Chácara Del Castilho, Fernão Cardim and Vidigal). From two groups: (1) from implementers: the architects, planners, politicians and social workers who designed and implemented the project, and (2) the community members who lived in the favelas before, during, and after urban upgrading projects. There were 40 semi-structured interviews with the two groups in Rio de Janeiro in January 2011. All of these interviews were in person. For the implementer category, I selected a representative sample of 10 from a pool of +500 possible interviewees fitting the category of being part of the process, based on their mix of expertise and that they have worked in the favelas where I interviewed community members. About $40 \%$ of the group were women, ages of all members of the group range from 40 to 65 years old. The implementers included senior professionals, directors of all the architectural firms that worked on three case favelas, the former director of the Secretaria Municipal de Habitação (SMH), SMH staff who worked and continued working on "urbanization of favelas" projects, and the former Mayor of the city of Rio de Janeiro. 
All interviews happened in the offices where these professionals work in different locals around the city of Rio and three in the research favelas themselves.

For the community group, I interviewed residents of the favelas who have lived through the planning and development of the projects and who still live in those neighborhoods. I selected these community members using a snowballing technique (Bertaux \& Bertaux-Wiame, 1981), starting with access to the three favelas (Chácara Del Castilho, Fernão Cardim, and Vidigal) in two ways. The first was through individuals recommended by the social worker team of the FB project Posto de Orientação Urbanística eSocial (POUSO). The second was through random selection in the community selected for analysis (favelas). Given the sensitive nature of the security questions, all interviews in this last group were performed in the community members' homes in an attempt to ensure that each felt safe and comfortable. One-third of the interviewees was between the ages of 25 to 44 and the rest ranged from 45 to $65+$.

Finally, building on the interviews I use mapping of perception to see a variation of perception of security values regarding infrastructure improvement. Interview responses were coded and included in the metadata of the geolocated interviews; this method provided a variable that rated interviews responses to conditions of security, a form of cognitive maps (Fuhrmann, Huynh, \& Scholz, 2013). Community members rate the value of physical interventions of the FB project, such as roads, services, public buildings, and public spaces. Interviewees were asked to explain variations of the condition of security before and after project intervention. Geo-tagging location of interviews permitted to perform a "spatial cluster analysis for point data" (Lu, 2000) to evaluate how interviewee's responses related to ways in which projects affected their homes.

\section{Understanding the Connection of Urban Upgrading and Security}

UN-Habitat estimates the slum dweller population at 863 million (Habitat, 2013). From that, 110.7 million are located in Latin America and the Caribbean. Urban poverty is the result of structural conditions of our capitalist society. Informal settlements (Slums) are the physical representation in cities of such phenomena. As Alan Gilbert affirms, "rather than providing a threat to the political and economic system, invasions and pirate urbanizations actively support it" (Gilbert, 1981, p. 657). Slums differ in size and other characteristics from country to country; most lack reliable sanitation services, the supply of clean water, reliable electricity, proper law enforcement, and other essential services (United Nations Human Settlements Programme, 2003). Governments and international agencies employ on-site upgrading to improve conditions in squatter settlements (Pugh, 2000; Satterthwaite, 2012). States and agencies see urban upgrading as a solution to the challenges of state provision of housing and a move to support the self-help housing sector (Bhattacharya, 1990; Gilbert, 1992; Pugh, 1994, 2000; Imparato \& Ruster, 2003; Satterthwaite, 2012) “Typically, area upgrading projects aim to improve infrastructure in a comprehensive package that includes water, sanitation, drainage, solid waste removal, and roads and footpaths. Also some form of tenure security" (Gilbert, 1992, p. 242). Upgrading is not only a way to improve services but a stepping stone towards the support and increase of commercial activities (Gilbert, 1998; McCallum \& Benjamin, 1985; Strassmann, 1987). In the 1970's the World Bank implemented the first applications of the idea of urban upgrading as an alternative to urban renewal applied alongside site and services projects (Abbott, 2002). In Latin America the IDB urban upgrading projects started by the 1980s decade (Rojas et al., 2010).

Initial projects of upgrading were focused only on service provision, over time, with the acknowledgment of the structural elements within poverty partly acknowledged in the set of millennium goals (Cukrowski et al., 
2006), Agencies' recommendations added projects beyond service provision. This new approach is what has come to be known as a multi-practice approach (Riley, Fiori, \& Ramirez, 2001; United Nations Development Programme, 1992, 2009; Franz. Vanderschueren, Wegelin, \& Wekwete, 1996). This new approach to upgrading follows the same framework defined in seven different policy guidelines (Riley et al., 2001). These guidelines, implemented in the neighborhood upgrading programs, emphasize that (1) poverty is a complex and multifaceted problem; (2) the need for a multi-sectoral approach; (3) design as a vehicle forsocial and physical integration; (4) that because of the scale of the problems of poverty (and informality) the project needs to be of sufficient scale to have an impact on the extent of the city; (5) that public and private partnerships are needed, (6) the engagement in these type of projects require some level of state reform; and (7) the pursuit of inclusion, participation, and democratization. An overarching goal of upgrading programs with these interconnected projects is to close the gap between the formal city and the informal settlements (Riley et al., 2001; Samper Escobar, 2010).

Ananya Roy criticizes urban upgrading limitations because it focuses mainly on the physical aspect but not on the livelihoods or what she calls the "aestheticization of poverty" (Roy, 2005). This critique is a response to the renewed interest in the spatial process in the last decades as a way to deal with problems of urban informality. Jorge Fiori and Zeca Brandão argue that over the years "there has been a growing de-specialization of slum upgrading strategies" resulting from the critique of the modern and traditional "spatially deterministic approaches throughout the world" (Fiori \& Brandão, 2010, p. 183). However several authors agree that from the components that comprise urban upgrading, the physical design has a positive role in improving the spatial dimensions of slums (Garau, Sclar, \& Carolini, 2005; United Nations Human Settlements Programme, 2003). This spatial component of upgrading is the variable that this research focuses on because this aspect is the one that resonates with the goals of security.

\section{Upgrading and Security}

Urban upgrading as a practice has in abstract been divorce from security goals. In recent years, a connection between the practice upgrading as contributing to security issues appears recurrent in media (Phillips, 2010), and in program publications (González Alcocer et al., 2010; Van Bronkhorst, 2003, p. 10). Most of this claim come out of the spatial intersection of policies to alleviate poverty and security practices in the spaces of informality (Slums). Dennis Rodgers present this intersection of violence and urban informality as the continuation of national conflict from the rural areas to the urban areas and within the urban to the marginal areas in that he coined the "slum wars" (Rodgers, 2009; Van Bronkhorst, 2003).

Prevalent in the literature about non-state armed actors is their exerting state-like functions in the informal settlements (Blake, 2013; Davis, 2009). Caroline Moser defines the relationship between what she calls "perverse organizations" (POs) (Moser \& McIlwaine, 2004) and their use of social capital in the neighborhoods where they operate, thus linking the conditions of the contexts where these organizations operate with their subsistence. These works present the spaces of informality as auspicious locales for the establishment of illegal armed groups, presenting the defining features of what make a slum as similar to those conditions that permit the formation of violent groups. Some authors present the defining features of informal settlements "in creating fertile soil for the development of violence and in generating a sub-culture of violence" (Vanderschueren, 1996, p. 99). State absence is another contributing feature to the unruly violence that occurs in these spaces by illegal structures of power (Arias \& Rodrigues, 2006; Penglase, 2005). Others present the actual urban form as favorable for the operation of non-state actors against the security apparatus of the state. Street networks made 
of narrow winding streets make policing more dangerous and challenging (Weizman, 2007). Urban upgrading squarely attacks to those defining features of what an informal settlement is but also indirectly diminishes the characteristics of what make them a place fit for asymmetrical warfare; this is the reason for much of these political assertions.

In the field of urban design, this idea of space as a tool for security is very rooted. From Baron Haussmann, urban intervention in Paris as a tool to mobilize troops and prevent uprisings (Jordan, 1995), to the ability to enforce community surveillance, by the way, private and public space are layout in the concept of "eyes on the street" (Jacobs, 1961). To the critic of the modern urbanization in the context of social housing that disfavors un-program public space and presents rules to create a "defensible space" (Newman, 1972). These ideas became the practice of "Crime Prevention through Environmental Design CPTED" (Jeffery, 1971; Schneider, 2006). These theories and practices present urban infrastructures, such as better accessibility thru roads, views, and active spaces as key contributors of secure neighborhoods. These ideas translate well within the goals of urban upgrading. They do tacitly correlate with the way the physical goals of urban upgrading projects play in the modification of the usually dense and complex space of the favela. These rules emphasize the role of modifying space as a way to control violence and poverty. It explains, in part, the weight these upgrading projects place on the modification of the physical environment of the "slums" as a way to change conditions (perceived and real) of security. Eduardo Rojas presents this confluence clearly in his review of the evolving nature of urban upgrading programs by the International Development Bank IDB:

Although it was generally expected that physical and social improvements would improve security conditions, neighborhood upgrading programmes were not originally designed with this specific objective in mind. This trend parallels recent changes in programmes aimed at reducing violence and improving security, which include measures to improve living conditions in the targeted communities as a way of tackling the problem of violence at its root. Out of this convergence, a new kind of programme has emerged featuring environmental prevention measures (such as the elimination of unsafe areas and increased community control over public spaces) directed at reducing some of the conditions that create insecurity, as well as preventive social actions targeted at those groups most likely to become the victims of violence (women) or its perpetrators (youth, especially school dropouts). (Rojas et al., 2010)

Elizabeth Riley evaluates the FB urban upgrading programs and argues that, "[n]ew roads are intended to improve access to emergency services; new social facilities they are intended to make residents re-evaluate their opinion of the state and of themselves as citizens' entitled to equal treatment; and new community spaces are intended as means to diminish the domain of the traffickers" (Riley et al., 2001, p. 527). Furthermore, it concludes that the urban interventions dismantled the formal barriers of protection that POs had constructed to "protect their territory from police and rival gangs". However, Riley also points out that contrary to these project assertions, residents also saw this strategy as making them more vulnerable to aggression by increased police repression (Riley et al., 2001, p. 527).

Table 1 List of UPP and Urban Upgrading Programs. Here is visible a correlation between UPP location and favela upgrading. Upgrading is performed by multiple projects such as the FB, Programa de Aceleração do Crescimento PAC (Growth Acceleration Program) and the Morar Carioca MC (Source: Jota Samper, Secretaria da habitação Rio de Janeiro, and http://www.upprj.com/index.php/historico).

Table 2 Urban upgrading and Unidade de Polícia Pacificadora (UPP) implementation in Rio de Janeiro. Correlation between UPP location and favela upgrading. Upgrading by multiple projects such as the FB, Programa de Aceleração do Crescimento PAC (Growth Acceleration Program) and the Morar Carioca MC. 
Table 1

Urban Upgrading and Unidade de Polícia Pacificadora (UPP)

\begin{tabular}{|c|c|c|c|c|c|}
\hline UPP & Name & Area & $\begin{array}{l}\text { Favela Size } \\
\text { Units }\end{array}$ & $\begin{array}{l}\text { Urban Upgrading } \\
\text { Program }\end{array}$ & MC Priority \\
\hline $1^{\mathrm{a}} \mathrm{UPP}$ & Santa Marta (Dona Marta) & Botafogo & 1262 & P.Est.de & ee \\
\hline $2^{\mathrm{a}} \mathrm{UPP}$ & Cidade de Deus & Jacarepaguá & 24 & PAC 2 & 1 \\
\hline $3^{\mathrm{a}} \mathrm{UPP}$ & Jardim Batan & Realengo & 505 & PAC 2 & 1 \\
\hline $4^{\mathrm{a}} \mathrm{UPP}$ & Morro da Babilônia/ Chapéu-Mangueira & Leme & 381 & Bairrinho & ee \\
\hline $5^{\mathrm{a}} \mathrm{UPP}$ & Cantagalo-Pavão-Pavãozinho & Copacabana, Ipanema & 1283 & PAC & ee \\
\hline $6^{\mathrm{a}} \mathrm{UPP}$ & Ladeira dos Tabajaras/Morro dos Cabritos & Copacabana & 317 & PAC & 1 \\
\hline $7^{\mathrm{a}} \mathrm{UPP}$ & Morro da Providência & Santo Cristo, Gamboa & 930 & FB II & 1 \\
\hline $8^{\mathrm{a}} \mathrm{UPP}$ & Morro do Borel & Tijuca & 1844 & FB I - PA & ur \\
\hline $9^{\mathrm{a}} \mathrm{UPP}$ & Morro da Formiga & Tijuca & 1515 & FB I - PA & ee \\
\hline $10^{\mathrm{a}} \mathrm{UPP}$ & Morro do Andaraí & Andaraí & 500 & FB I & ur \\
\hline $11^{\mathrm{a}} \mathrm{UPP}$ & Morro do Salgueiro & Tijuca & 910 & FB I & ur \\
\hline $12^{\mathrm{a}} \mathrm{UPP}$ & Morro do Turano & Tijuca,Rio Comprido & 359 & FB I & ur \\
\hline $13^{\mathrm{a}} \mathrm{UPP}$ & Morro dos Macacos & Vila Isabel & 914 & FB II & 1 \\
\hline $14^{\mathrm{a}} \mathrm{UPP}$ & Morros São João/ Matriz and Quieto & Engenho Novo & 318 & FB III & 2 \\
\hline $15^{\mathrm{a}} \mathrm{UPP}$ & Morros da Coroa/ Fallet and Fogueteiro & Catumbi & 1022 & FB III & 1 \\
\hline $16^{\mathrm{a}} \mathrm{UPP}$ & Morros dos Prazeres/ Escondidinho & Santa Teresa & 333 & FB I & ee \\
\hline $17^{\mathrm{a}} \mathrm{UPP}$ & Complexo do São Carlos & Estácio & 1793 & FB II - P & ee \\
\hline $18^{\mathrm{a}} \mathrm{UPP}$ & Morro da Mangueira/Morro do Tuiuti & São Cristóvão & 566 & FB I & 2 \\
\hline $19^{\mathrm{a}} \mathrm{UPP}$ & Vidigal/Chácara do Céu & Leblon & 2757 & FB I & 1 \\
\hline $20^{\mathrm{a}} \mathrm{UPP}$ & Fazendinha & Complexo do Alemão & 151 & PAC & 1 \\
\hline $21^{\mathrm{a}} \mathrm{UPP}$ & Nova Brasília & Complexo do Alemão & 4290 & PAC & ur \\
\hline $22^{\mathrm{a}} \mathrm{UPP}$ & Morro do Adeus/ Morro da Baiana & Bonsucesso and Ramos & 355 & PAC & ur \\
\hline $23^{\mathrm{a}} \mathrm{UPP}$ & Morro do Alemão / Pedra do Sapo & Complexo do Alemão & 2829 & PAC & ur \\
\hline $25^{\mathrm{a}} \mathrm{UPP}$ & Morro da Chatuba / Morro da Caixa D'água & Penha & 618 & FB I & 1 \\
\hline $24^{\mathrm{a}} \mathrm{UPP}$ & Morro do Sereno / Morro da Fé & Penha & 254 & FB I & 2 \\
\hline $26^{\mathrm{a}} \mathrm{UPP}$ & Morro Santo Amaro & Catete & 343 & FB III & 1 \\
\hline $27^{\mathrm{a}} \mathrm{UPP}$ & Vila Cruzeiro & Penha & 5593 & FB III & 1 \\
\hline $28^{\mathrm{a}} \mathrm{UPP}$ & Rocinha & São Conrado & 16999 & PAC & 1 \\
\hline $29^{\mathrm{a}} \mathrm{UPP}$ & Favela de Manguinhos & Manguinhos & 80 & PAC & 1 \\
\hline $30^{\mathrm{a}} \mathrm{UPP}$ & Jacarezinho & Jacaré & 8712 & Grandes F & 2 \\
\hline
\end{tabular}

Source: Jota Samper, Secretaria da habitação Rio de Janeiro, and http://www.upprj.com/index.php/historico

Evidence shows that urban upgrading plays a significant role in state security strategy as preparing the environment of favelas to implement other security policies. An example of this is the placing of Unidade de Polícia Pacificadora, UPP (Pacifying Police Units) in already upgraded favelas. Table 1 presents this relationship of UPP and the level of upgrading of each favela, suggesting that favela urbanization (physical transformation) that increases mobility of diverse actors and that opens public spaces is a prerequisite for armed state control (Weizman, 2006), and to implementing these new policing practices. The question then emerges, how those two ideas of upgrading and security play out in the FB project?

The Fabela-Bairro urban upgrading project, bringing together two epistemological approaches to deal with security.

The FB Project implementers did not intend its use as safety strategy through the use of environmental design. However, the main spatial dimensions of this project intersect with those ideas of how environmental 
design can increase levels of security. Among those are the improving of accessibility, creation of an active public space, and removal of physical signs of "disorder behavior" (Wilson \& Kelling, 1982). The FB in Rio de Janeiro, Brazil, is the first of a generation of urban upgrading projects based on Riley et al.'s (2001) policy concepts. It is also the project that serves as a model for many other similar projects in Latin-America, such as the Medellin Integrated Urban Project (UIP) (Samper Escobar, 2010) and the CONAVI in Caracas (Cruz, 2010; Brillembourg \& Klumpner, 2010; Brillembourg, 2004). The policy approach and physical interventions of these projects follow a multi-practice approach, and Cities also implemented these projects in areas in which illegal armed actors (drug traffickers) operate in open contestation of the legitimacy of the formal state power structure (Koonings \& Kruijt, 2007; Penglase, 2005). Interventions in Rio have pursued the broader goal of incorporating these informal settlement areas into the formal fabric of the city. The multi-practice approach was a political strategy of the state to gain legitimacy in these same areas where the "state before was dissociated" (Rabello de Castro, 2002, p. 153). This case becomes important considering that the upgrading happens under conditions of violent conflict, which is still present in many favelas.

\section{Case Study Favela-Barrio in Rio de Janeiro}

FaveIa-Bairro was an innovative project of poverty alleviation that emerged from what municipalities and agencies had implemented in previous decades known as "a comprehensive upgrading approach to the favelas" (Pamuk \& Cavallieri, 1998). The municipality of Rio de Janiero and Inter-American Development Bank (IDB) developed the FB program from 1994 to 1999 . The total cost of the project was $\$ 380$ million from which the IDB provided a loan for $\$ 180$ million, and the rest of those funds came from the municipality of Rio itself (Imparato \& Ruster, 2003, p. 88). The FB project aims to "integrate slums into the city by providing access to the population of favelas to basic services and infrastructures as well as the regularizations of this public and private spaces" (Rabello de Castro, 2002, p. 151). The FB project upgraded 140 favelas and is one of the largest slum-upgrading programs to date in Latin America (Riley et al., 2001). The program aims to provide city-standard quality of services to the selected favelas. Key projects for each favela are:

That provide accessibility by main and secondary roads; provision of water and sewerage; the availability of electricity; public areas for leisure and sports; public works to contain erosion; as well environmental projects, such as reforestation. Other important aspects are the removal of houses from high-risk areas and the clearing of places where projected passageways, roads, and common social spaces are to be built. (Rabello de Castro, 2002, p. 156)

Administratively the project was led by the newly created Secretariat of Housing of the municipality of Rio de Janeiro. Given the focus on physical interventions part of the upgrading process, the municipality contracted out the design and implementation to architectural firms selected thru competition, as a way to compensate for the lack of operational capacity of the secretary of housing (Magalhães, 2011). By competition 15 firms were selected (Duarte, Silva, \& Brasileiro, 1996). This group implemented the first 15 favelas upgrading projects and later become the sole implementers of all 140 total favelas upgraded. Some of these offices are still active and continue developing similar projects in Rio de Janeiro and other cities.

For the first set of favelas upgraded the housing Secretariat develop a methodology in which autonomy was given to the architectural firms to determine the type of physicalprojects needs at each location. As an accountability system, satellite offices of the architectural firms would be located at favela sites. Community meetings would be setup with the neighborhood association (Associação Moradores) at each location to approve final plans. This on-site contact gives professionals at the municipality and architectural offices first 
account of physical conditions but also of the security environment in which inhabitants of this places lived. Two years later after 1995 when the IDB funding was approved, international standards for urban upgrading were setup and those two previous requirements were no longer needed (Magalhães, 2011; Maia, 2011). This project focuses on those favelas because of the close contact between communities and implementers.
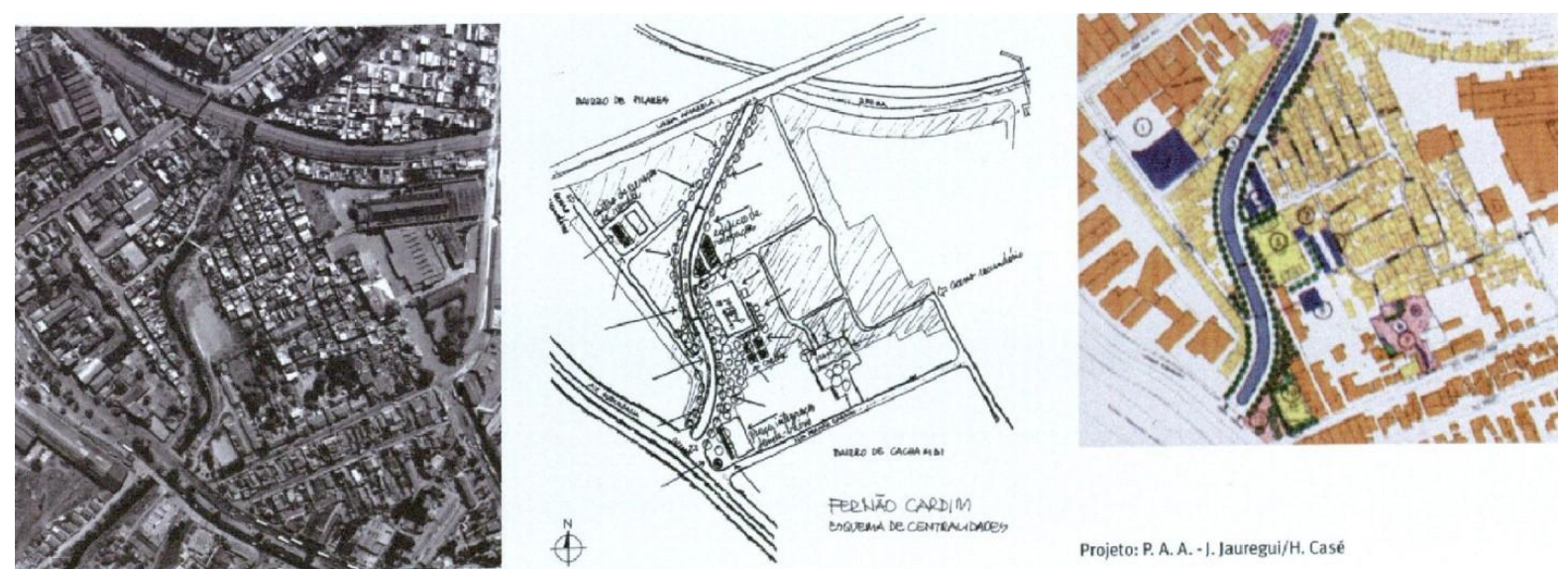

Figure 1. Jorge Mario Jáuregui Diagrams (areal, sketch and project plan) of FERNÃO CARDIM.

Source: Conde \& Magalhães, 2004.
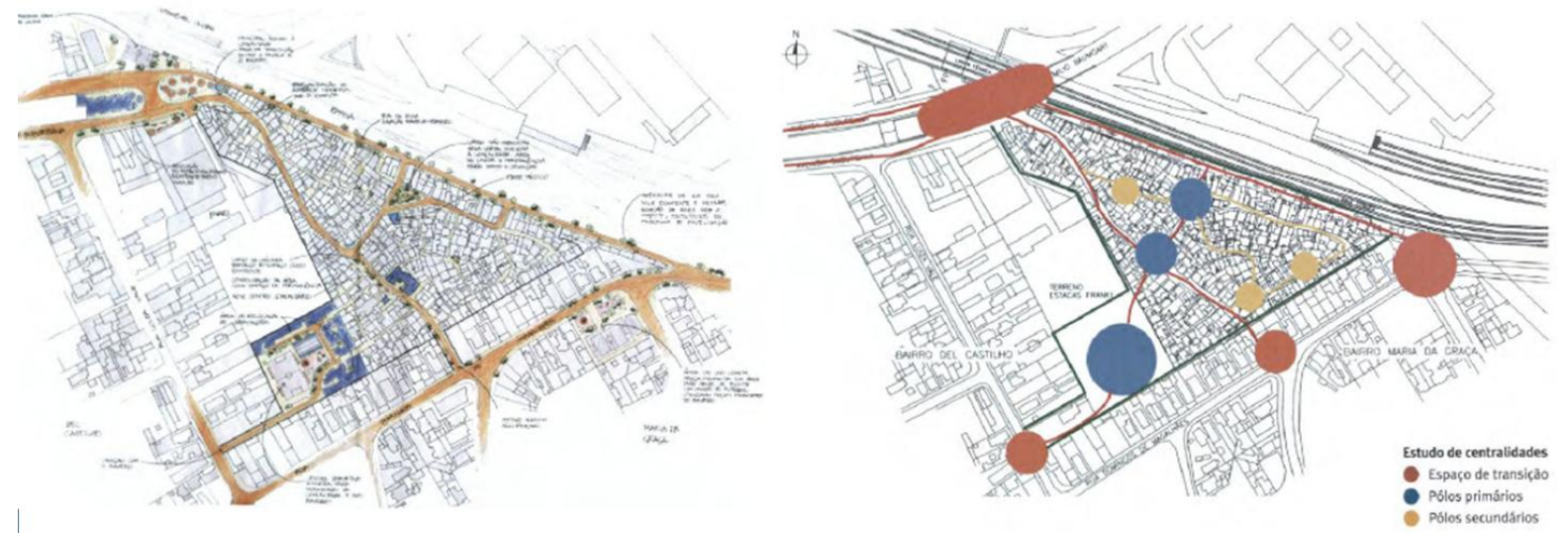

Figure 2. Arqui Traco Cooperativa Diagrams of Chacara Del Castilho.

Source: Conde \& Magalhães, 2004.

The FB neighborhood upgrading programs aimed to integrated the favelas into the formal fabric of the city through four interconnected projects: (1) completion of basic urban infrastructure; (2) physical urban reconfiguration of the favela through new street grids ordering, and the construction of new public buildings; (3) provision of social services of income generation and training programs; and (4) legalization of land tenure. Two of those categories concentrate on the physical form showing a preponderance of physical over other community needs. Some authors critique the emphasis of the FB on the limits of the physical approach (De Souza, 2005, p. 11; Fernandes, 2006). Specifically, the FB program's physical projects included the widening and paving of roads, provision of service infrastructure (power, water, and sewer), public plazas, and public buildings (daycare facilities, or community centers). In general, all FB projects followed three formal strategies of favela "urban reconfiguration". Spine, an existing street (or group of streets) is selected to be the primary road of each favela project. This street usually connects the interior of the favela to a network of streets on the outside and the city at large, functionally and symbolically reconnecting the community to its larger urban 
context. This street serves as the spine of the project in each favela, in some cases is the only road wide enough that admits vehicles. The spine is the armature along which to situate other projects such as public spaces, and buildings. Paving of streets this include the installation of the sewer system and when a high slope is presented paths become steps. Removal of Houses located in the path of new roads, or high environmental risk areas. This type of projects increases open space. Inhabitants affectedare relocated in infill housing projects (Rangan, 2007). Examples of such spatial strategy are the diagrams for the FB Project for Fernão Cardim by Escritório Planejamento Arquitetônico e Ambiental led by the architect Jorge Mario Jáuregui and a similar diagram in the favela Chacara Del Castilho by the architectural firm Arqui Traco Cooperativa led by Solange Libman are examples of such a spatial strategy (see Figures 1 and 2).

\section{Three Favelas as Case Studies}

The three selected case studies, favelas: Vidigal, Chácara Del Castilho, and Fernão Cardim. Following is a brief description of the physical scope in each favela.

\section{Vidigal}

Located on a hillside high sloped adjacent to the high-income neighborhoods of the South Zone (Copacabana and Ipanema). Limits to the west with a natural reserve, to the east and with the Av. Niemeyer. A large favela of 23.7 hectares with a population of 9,943 inhabitants at the time of upgrading. The first settlement occurred around 1941 between Av. Niemeyer \& Vidigal beach. In 1951 dwellings below the Av. Niemeyer removed and placed on land above the road. With the establishment of the Residents' Association in 1967 main evictions were avoided. This favela upgrading had a total investment of R \$6 million. The Escritório Planejamento Arquitetônico e Ambiental led the upgrading. The main components of the project are a main public space as a point of entry over the Niemeyer Avenue with a plaza, paving and widening of the main road, the location of public spaces and amenities alongside this corridor (road) including a training center, multi-purpose gymnasium, and soccer field.

\section{Chácara Del Castilho}

Chácara Del Castilho (Country House of Del Castilho) located in the North Zone of the City between the neighborhoods of Del Castilho and Maria da Graça. This area is a mix of middle-income residential and industrial. The site is in a sloped area bordering a rail line and the main highway, the Linha Amarela (Yellow Line Highway). A small favela of 2.7 hectares with a population of 2,184 inhabitants at the time of upgrading. The occupation of this area began around 1950 by low-paid workers and immigrants from the Northeast. The project funded with an investment of $\mathrm{R} \$ 2$ million and led by the offices of Arquitraço Cooperativa. The upgrading comprised of the widening of the main street (Maria de Fátima Street), including the widening of the existing entrance across from the Emílio Baumgart Viaduct and the opening of the second connection to the west toward to the Domingos Magalhães Street. Along this main road, a public building was erected for the offices of the POUSO (Posto de Orientação Urbanística e Social, Center for Urban and Social Assessment). Secondary streets were paved, and public open space was also equipped with landscape, sitting areas, and a playground.

\section{Fernão Cardim}

Named in honor of the first priest in the favela, who lead residents land claim efforts. Located between the Méier and the Engenho de Dentro Neighborhoods in the North Zone in a low flood plain of the Faria River. A 
cattle ranch that later became an industrial area. With an area of 4.5 Hectares and a population of 3,413 at the time of upgrading today around 20,590. This favela is a 1950s occupation through the process of upgrading of the FB on 6 May 1999 the Mayor signed a decree elevating Fernão Cardim's status to a "bairro" (neighborhood). The project began with an investment of $\mathrm{R} \$ 5$ million. Led by the Escritório Planejamento Arquitetônico e Ambiental. Focus on the channel of the Faria River to protect the neighborhood from recurrent flooding during rainy season. Parallel to the channel new roads were paved. It also included open spaces, public buildings, new apartments for resettlement, soccer field, daycare center, square, and the POUSO. A main open space called the Praça das Tamarineiras includes a meeting place for the community, with playground equipment for children and serves as an entry point to the favela.

Table 2

Case Studies

\begin{tabular}{|c|c|c|c|c|c|c|}
\hline Favela & Design & Housing Units & Population/people & Investment/R \$ million & Area/ha & $\begin{array}{l}\text { Illegal armed } \\
\text { group on site }\end{array}$ \\
\hline Vidigal & $\begin{array}{l}\text { Escritório Planejamento } \\
\text { Arquitetônico e Ambiental }\end{array}$ & 2,567 & 9,943 & 6 & 23.7 & $\begin{array}{l}\text { Amigos dos } \\
\text { Amigos }\end{array}$ \\
\hline $\begin{array}{l}\text { Chácara Del } \\
\text { Castilho }\end{array}$ & Arquitraço Cooperativa & 644 & 2,184 & 2 & 2.7 & milícias \\
\hline Fernão Cardim & $\begin{array}{l}\text { Escritório Planejamento } \\
\text { Arquitetônico e Ambiental }\end{array}$ & 875 & 3,413 & 5 & 4.5 & milícias \\
\hline
\end{tabular}

Source: SMH For FB Data and for Illegal Armed Group on Site (Abdala, 2009).

As the city, over the years, these favelas had had variations of levels of security. Turf-related conflict increased the risk of homicide. The transition from the domination from one group to another is a period where violence is felt strong by community members (Barcellos \& Zaluar, 2014). Security in the three favelas at the time of interview varied, two favelas Fernão Cardim and Chácara Del Castilho had a presence of Milicias a phenomenon relative recent in Rio (since 2008), while Vidigal has the presence of the armed group Amigos Dos Amigos. The next section focuses on residents' and planners' views of how the projects part of the FB affected their lives in the context of violent conflict by these armed actors.

\section{Evaluating the Impact of Physical Projects on Security}

\section{Physical Projects and Security}

Interviewees were asked to narrate in their words an evolution of the physical space of the neighborhood. Presenting evidence of previous conditions versus the present after years of project implementation. They evaluated each of the main project components such as roads, services, public buildings, and public spaces regarding the improvement of the quality of life. They also were asked to present a history of security conditions as evolving over their lived experiences in these neighborhoods. Interviewees responded to their impressions of how perceived changes in security conditions related to the specific project components of the FB projects.

Overall interviewees see the intervention of the FB as a very positively regarding improving their quality of life. Most narratives of foundation and favela before FB expose the precarious conditions in which they had lived. These views are consistent even when still there are many things to improve or when some of the projects implemented during that time had already decayed for lack of maintenance. Sewer, trash collection, and roads were the components on the top of the list. Tenure was a more complex issue to generalize since it varied from favela to favela regarding implementation and also on the level of interest to obtain legal title. From those 
elements that comprise the upgrading program interviewees agreeroads improvement, that comprises widening of the main road for vehicular use and paving, are the ones that most impact the everyday life of communities. The increase in mobility both by residents and foreigners are often mentioned during the interviews are signs that things today are better than before project implementation. Interviews mention the rise in housing prices as a result of the project implementation and that today it is harder to find affordable housing solutions in their neighborhood. A kind of "favela gentrification" process today happening in Rio (Cummings, 2015). Increase density related to site attractiveness after FB project is also one the impacts that residents mention as evidence of the project success.

Interviews presented a unified picture of security in favelas over the last 20+ years, one that agrees with many other scholars, which present criminal organizations in their neighborhoods as more organized and embedded within other political, social, and economic structures (Arias, 2004; Arias \& Rodrigues, 2006; Perlman, 2010). Meaning that the type of criminal organizations that acted in the favelas at the time of FB where less capable of exercising a monopoly of violence. This escalation of the capacity of drug trafficking factions happens across Rio de Janeiro in upgraded and non-upgraded favelas. Ninety percent of interviews express that FB implementation provided positive changes regarding security.

Regarding security, the widening and opening of streets are presented as a contributing factor to that picture of security. An interviewee mentioned why she felt more secure in Chácara Del Castilho after the project. She explained that "with the project [public] space was now more open" (Chácara Del Castilho 010, 2011). Another interviewee in the same neighborhood explained that the opening of alternative exits open the favela avoided lockdowns and that now even vehicles can move freely. These mobility increases were not welcome by all interviewees; some saw this as facilitating access to criminal actors to their neighborhood "after they [FB] open [the street] up there, people were able come in and out, you do not know who they are. Before they would arrive in motorcycles and park here [on the front of my store] and they will ask [pointing her finger making the sign of a gun] to give them everything. However, from five years on things improved I do not know why, but they did" (Chácara Del Castilho 017, 2011). A community member interviewed in the favela of Chacara Del Castilho said, "After the projects the security improved a lot. Because when the street improves this [in turn] improves security". In Vidigal, for example, this condition of improving security thanks to the roads is also attached to the arrival of tourists as a positive indicator of better levels of security. Interviewees also linked increased mobility within their communities and between their communities and the city at large, which they cited as coming from the FB projects' new streets and the pavement of existing ones to increases in violence by external actors in their neighborhoods. Others viewed this rise in mobility as a factor that had decreased levels of crime susceptibility in their neighborhoods because it permitted larger flows of people in and around them.

Residents feel the FB brought positive aspects concerning security, a champion among those were the presence of more outsiders and non-repressive state actors such as those that filled the spaces built by the upgrading as the POUSO. However, this presence of foreigners was seen by some interviewers as negative and to contributing to the varied levels of security that happen over the years. Still, community members remain positive even when that mobility brings with it the negative effects of facilitating access of POs and also the repressive state to their communities.

For the implementer group, direct connections between the modification of the formal space of the favela and the changes in conditions of security are more tacit (if not total denial). In the interviews, the discussions of 
the expert group focused on abstract ideals of favela integration with the formal city and left out discussion of space as a tool for crime control, which they see as a problem that needs to be resolved by other state organizations. In general, this group emphasized the importance of the provision of public space as a fundamental tool for favela integration. To them public space them, is equated with public participation in the larger political system of the city. The direct connection between public space and control of POs has receded. Contrary to this view the municipality's actions clearly link favela upgrading as a tool to secure the city for the upcoming Olympic Games (see Figure 3). As part of the ambitious project to upgrade all favelas by the year 2020, the city of Rio has developed a plan called Morar Carioca led by most of the same actors than the FB. In the stages of this project, priority to upgrade is given to favelas close to Olympic sites within what is called the "Security Polygon", directly linking upgrading as a security tool. Favelas within the polygon of security of main events become a priority to be urbanized. Here, upgrading enhances safety conditions and becomes a requisite necessary to secure the city for the global event.

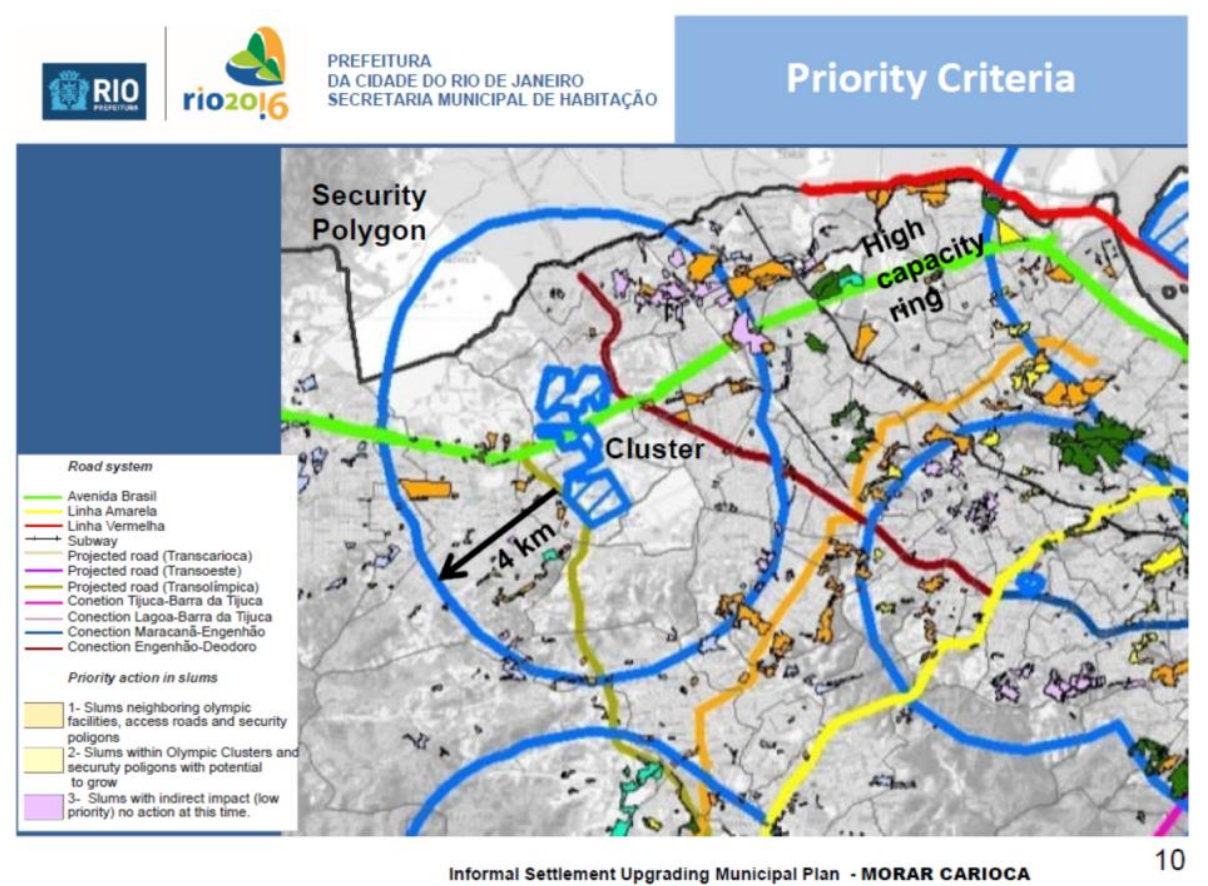

Figure 3. Priority criteria for current upgrading practices in Rio de Janeiro in which favelas inside of the Security

Polygon acquire priority for upgrading than those outside of such areas.

Source: SMH Rio de Janeiro.

The implementer group relates the presence of illegal armed groups during the time of project planning and construction to today. The present variation between the current presence of armed actors and what happened in the past Pedro da Luz Moreira, the principal of Archi 5 Arquitectos: "At the time of the FB there were drug dealers, but they were not arrogant as the one's today... they had weapons, but not of such high caliber and number as the one's today". Literature that presents current security situation in favelas in Rio as dominated by larger criminal groups that compete for turf control corroborate this story (Barcellos \& Zaluar, 2014; Zaluar, 2000, p. 663). These groups increase their institutional sophistication thru the use of violence (Batista \& Burgos, 2008). This change from the gangs of the early 1990s to more organized crime is the one that overwhelms the capacity of state organizations. This group presents a fascinating story of upgrading in the 
context of armed conflict. One that happens on varied scales; violent conflict between police or other armed actors delayed and impacted the favela upgrading. Bidman explained: "We have had many problems working, because of the war [between police and drug dealers]. At some point, we had to stop working on a project in a favela for 140 days". The other scaled presented planners negotiating space in control of armed actors for the development of projects of the FB directly changing the configuration of turf control by perverse actors. A planner comments about how he strategized with community members to get control of open space in the one of the favelas that were in the control of the local armed group to build a football court.

Regarding perceptions planners and community disagree about what are the real impacts of security that projects bring to their spaces, while planners' rhetoric still focus on public space as a democratic space. Communities experience the complex contradiction that comes with the improvement of infrastructures and the increased accessibility of their neighborhood in which more open space and sight views increase the feeling of security. However, increased mobility is mirrored by the ability of external actors to deploy violence. Among those acts of violence executed by foreign groups are also the repressive state tactics. However, how do those experiences narrated by community members reflect on the urban space? Additionally, more importantly, how do those relate to specific interventions?

\section{Mapping Security Perceptions and Project Infrastructure Developments}

The interviews revealed that road network improvement was seen as more relevant than any other type of project regarding the quality of life and also as playing an important role in the conditions of security. However, the FB projects are not distributed homogeneously over the territory. So how that reflects in how those improvements affect community members. A very plausible outcome is that residents close to FB projects could see these are more positives than those located far from them. Data from the interviews reveal not significant variations. However concerning security, the results are different presenting variations based on geographic location.

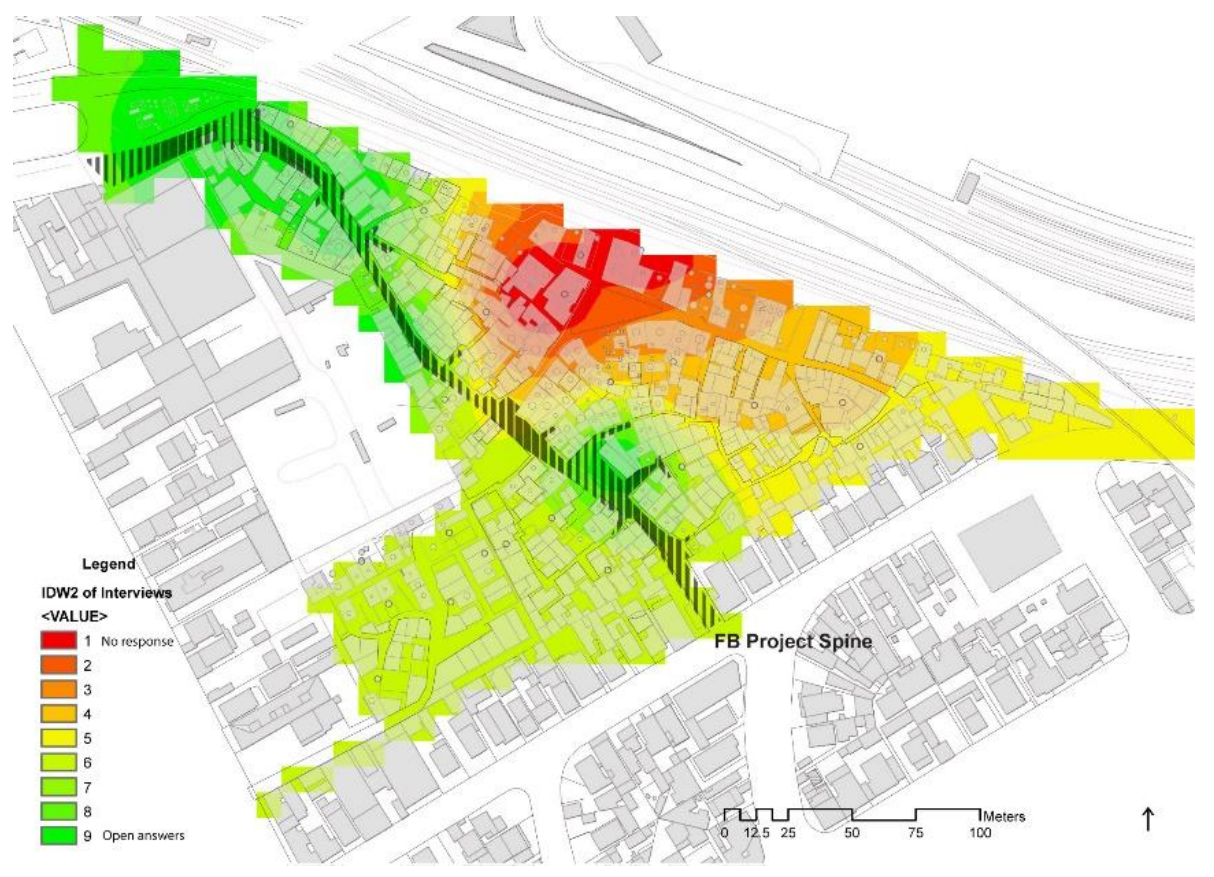

Figure 5. Chacara Del Castilho responsiveness to questions of security. 
All interviews happened in interviewees' homes permitting the geo-tagging of individual responses, making visible interviewees' responses as they relate to project features. Georeferencing interviews revealed a pattern over the three favelas. Reluctance to address issues of security in interviews, people who declined the interview on safety bases, and individuals who felt more comfortable sharing their views about security (increased or decreased), follow a spatial distribution pattern. Individuals who felt comfortable to voice security issues (good and bad) live in areas close to the main roads and FB public buildings, housing units located along the transportation spine of the favela, and close to areas of commerce and public buildings developed by the urban upgrading projects. The more distant units were from the main road; individuals were less at ease when responding and elaboration on the security questions. Closeness to public spaces (such as parks of playgrounds) had little influence on increasing willingness to talk about security issues. On the contrary, open spaces disconnected from the spine rated low, confirming some of the results from the scoring of what projects were more important to community members. This pattern was consistent across the three favelas. In Figure 4, maps responsiveness of interviewees to questions regarding security in the favela of ChacaraDel Castilho. This finding supports the recurring theme of how FB projects increased mobility. However, it provides a more complex understanding of the how such structural changes modified perceptions of security.

These results suggest that even if security has not decreased, the provision of this spine network provides impacts on the perception of safety, measured by a willingness to engage in discussions about security. This result resonates with the "space syntax" (Hillier, 1996, p. 144) application to conditions of security, in which the composition of space but also the mix of type of individuals on the street brought from the laying out of more interconnected street grids determine variations of levels of security. New roads that open the space to newcomers that enter to the neighborhoods create a different mix of individuals in the street proximate to the spine road than those distance from it. This condition creates a heterogeneous mix of persons on the spine street that provides arguably a larger sense of anonymity to residents in these areas. Areas with a homogeneous composition expose residents to higher levels of scrutiny by armed actors. The variation of levels perceptions of security by residents then is a result of the modification of access to the communities. This last element echoes ideas of modification of space of informality in warfare theory in terms that it sees informality as a physical body in which increasing mobility through infrastructure provides larger strategic military leverage (Weizman, 2006). There is the need for continued further study that focuses on how mobility networks impact security.

\section{Conclusions}

This study finds that the Favela Bairro interventions as part of the current Latin America typology of urban upgrading, create physical structural changes to the urban form of informal settlements. These physical changes to the road system permit a larger number of contacts on the street and also a greater mix of foreigners and residents. This condition, in turn, modifies not only the way spaces perform physically but also on how individuals see their personal security.

Three main findings are clear. First, changes in urban form affect the way in which communities perceive security conditions, not all in positive ways. Second, public infrastructure and buildings create available space for action of state security forces but also for other foreign actors. This intersection of urban upgrading as providing the ability of state security forces to intervene in spaces of informality controlled by POs and external actors is not all positive. The opening of the favela to external actors plays at multiple scales and with varied 
effects (positive and negative) for community members. Further research is needed to understand the real impacts of such intersection. This finding builds on the theories exploring the role of physical space in the production of violence. Thirds, states use urban upgrading projects as blankets that affect individuals in a homogenizing way. Upgrading practices' emphasis on the physical environment does not act homogeneously over the territory. The mapping provided here shows how their applications had particular heterogeneous various effects over the urban landscape and the community members that dwell in it. However, these findings need to be corroborated in other upgrading projects in Latin America. Future research would require more precise research tools to gauge variation in the level of responses and larger population sample.

In a global context where governments and agencies see informal settlements as spaces of violence and were municipalities and international agencies are engaging in processes of urban upgrading to protect vulnerable populations, there is an imperative need to understand the impacts of security that the upgrading is producing. This research found that most professionals working on this project of favela urbanization do not openly recognize a connection between the ways that the FB policies and physical transformation directly affect security in these favelas. In contrast, it shows that the state and local agencies use favela urbanization (urban upgrading) as a pre-requisite to access the space of the favela where they then implement old and new security strategies (like military operations and pacifying police). Among this contradiction lies the danger of not understanding the impacts these projects had on the populations that are trying to serve. Implementers of urban upgrading projects should place particular care in the design of transportation networks and the location, character, scale, and programs of the public building along transportation infrastructure because they determine (as the mapping of this paper presents) levels in the "distance from the state" of communities, distances the design and infrastructure can bridge.

\section{References}

Abbott, J. (2002). A method-based planning framework for informal settlement upgrading. Habitat International, 26(3), $317-333$.

Abdala, V. (2009). Distribuição das facções criminosas pelas favelas da cidade do Rio de Janeiro. Retrieved from http://favelascariocas.blogspot.com/

Arias, E. D. (2004). Faith in our Neighbors: Networks and social order in three brazilian Favelas. Latin American Politics and Society, 46(1), 1-38. https://doi.org/10.1111/j.1548-2456.2004.tb00264.x

Arias, E. D. (2006). Drugs \& democracy in Rio de Janeiro: Trafficking, social networks, \& public security. Chapel Hill: University of North Carolina Press.

Arias, E. D., \& Rodrigues, C. D. (2006). The myth of personal security: Criminal gangs, dispute resolution, and identity in Rio de Janeiro's Favelas. Latin American Politics \& Society Latin American Politics \& Society, 48(4), 53-81.

Barcellos, C., \& Zaluar, A. (2014). Homicides and territorial struggles in Rio de Janeiro favelas. Revista de Saude Publica, 48(1), 94-102.

Batista, A. S., \& Burgos, M. D. (2008). Brazilian gangs. In Encyclopedia of gangs. Westport, Conn.: Greenwood Press.

Bertaux, D., \& Bertaux-Wiame, I. (1981). Biography and society: The life history approach in the social sciences (Vol. 23). Sage publications Thousand Oaks.

Bhattacharya, K. P. (1990). Housing in India-observations on the Government's Intervention Policies. Housing Policy in Developing Countries, 67-103.

Blake, D. K. (2013). Shadowing the state: violent control and the social power of Jamaican garrison Dons. Journal of Ethnographic \& Qualitative Research, 8(1).

Blau, J. R., \& Blau, P. M. (1982). The cost of inequality: Metropolitan structure and violent crime. American Sociological Review, 114-129.

Brillembourg, A., \& Klumpner, H. (2010). Rules of engagement: Caracas and the informal city. In Rethinking the informal city: Critical perspectives from Latin America. New York: Berghahn Books. 
Brillembourg, C. (2004). The New Slum Urbanism of Caracas, Invasions and settlements, colonialism, democracy, capitalism and devil worship. Architectural Design, 74, 77-81.

Cerdá, M., Morenoff, J. D., Hansen, B. B., Hicks, K. J. T., Duque, L. F., Restrepo, A., \& Diez-Roux, A. V. (2012). Reducing violence by transforming neighborhoods: A natural experiment in Medellín, Colombia. American Journal of Epidemiology, 175(10), 1045-1053.

Chácara Del Castilho 010. (2011, January 31). 20110163 Urban Upgrading in a Context of Violence: physical space and security perception in the case of the Favela-Bairro in Rio de Janeiro.

Chácara Del Castilho 017. (2011, January 31). 2011017 Urban upgrading in a context of violence: Physical space and security perception in the case of the Favela-Bairro in Rio de Janeiro.

Conde, L. P., \& Magalhães, S. (2004). Favela-Bairro: uma outra história da cidade do Rio de Janeiro: 1993-2000: uma ação urbanizadora para o Rio de Janeiro. [Rio de Janeiro, Brazil]: ViverCidades.

Cruz, T., Samper Escobar, J., Rosenblum, A., \& Cuellar, A. (2010). Casa familiar: Living rooms at the border and senior housing with childcare. In A. Lepik and Museum of Modern Art (New York, N.Y.), Small scale, big change: New architectures of social engagement. New York: Museum of Modern Art.

Cukrowski, J., Kazmierkiewicz, P., Kling, J., \& United Nations Development Programme. Regional Bureau for Europe and the Commonwealth of Independent States. (2006). National Millennium Development Goals: a framework for action. Bratislava: UNDP Regional Bureau for Europe and the Commonwealth of Independent States.

Cummings, J., Shin Lees, L. H., \& López-Morales, E. (2015). Confronting favela chic: the gentrification of informal settlements in Rio de Janeiro, Brazil. Global Gentrifications: Uneven Development and Displacement, 81-99.

Davis, D. (2009). Non-State Armed Actors, New Imagined Communities, and Shifting Patterns of Sovereignty and Insecurity in the Modern World. Contemporary Security Policy, 30(2), 221-245.

De Souza, M. L. (2005). Urban planning in an age of fear: the case of Rio de Janeiro. International Development Planning Review, 27(1), 1-19.

Duarte, C. R., Silva, O. L., \& Brasileiro, A. (1996). Favela, um bairro $\square$ : propostas metodológicas para intervenção pública em favelas do Rio de Janeiro. [Rio de Janeiro, Brazil]; [São Paulo, Brazil]: Grupo de Pesquisas Habitat $\square$; Pro Editores.

Fernandes, E. (2006). Principles, bases and challenges of the national programme to support sustainable urban land regularisation in Brazil. Land and Urban Policies for Poverty Reduction, 191.

Fiori, J., \& Brandão, Z. (2010). Spatial Strategies and Urban Social Policy: Urbanism and Poverty Reduction in the Favelas of Rio de Janeiro. Rethinking the Informal City: Critical Perspectives from Latin America, 11, 181.

Fiori, J., \& Brandao, Z. (2010). In Rethinking the informal city: Critical perspectives from Latin America. New York: Berghahn Books.

Fuhrmann, S., Huynh, N. T., \& Scholz, R. (2013). Comparing fear of crime and crime statistics on a university campus. In M. Leitner (Ed.), Crime Modeling and Mapping Using Geospatial Technologies (pp. 319-337). Springer.

Garau, P., Sclar, E., Carolini, G. Y., \& UN Millennium Project. Task Force on Improving the Lives of Slum Dwellers. (2005). A home in the city. London; Sterling, Va.: Earthscan.

Gilbert, A. (1981). Pirates and invaders: Land acquisition in urban Colombia and Venezuela. World Development, 9(7), 657-678.

Gilbert, A. (1992). Third World cities: Housing, infrastructure and servicing. Urban Studies, 29(3-4), 435-460.

Gilbert, A. G. (1998). The Latin American City.

González Alcocer, M. E., Cohen, M., Oliveira, C. B. H. de, Santos, B. A. dos, Alvarado, N., Palenque, P., ... Fretes Cibils, V. (2010). Building cities: Neighbourhood upgrading and urban quality of life. Inter-American Development Bank.

Graham, S. (2012). Foucault's boomerang-The new military urbanism. The end of the development-security nexus? The Rise of Global Disaster Management, 37.

Habitat, U. N. (2013). Streets as public spaces and drivers of urban prosperity. Nairobi: UN Habitat.

Hillier, B. (1996). Space is the machine: A configurational theory of architecture. Cambridge; New York, NY, USA: Cambridge University Press.

Imparato, I., \& Ruster, J. (2003). Slum upgrading and participation: Lessons from Latin America. World Bank Publications.

Jacobs, J. (1961). The death and life of great American cities. New York: Random House.

Jeffery, C. R. (1971). Crime prevention through environmental design. Beverly Hills [Calif.: Sage Publications.

Jordan, D. P. (1995). Transforming Paris: The life and labors of Baron Haussmann. New York: Free Press.

Koonings, K., \& Kruijt, D. (2007). Fractured cities: Social exclusion, urban violence and contested spaces in Latin America. London; New York; New York: Zed Books; Distributed in the USA exclusively by Palgrave Macmillan. 
López, N., \& Lukinbeal, C. (2010). Comparing police and residents' perceptions of crime in a phoenix neighborhood using mental maps in GIS. Yearbook of the Association of Pacific Coast Geographers, 72(1), 33-55.

Lu, Y. (2000). Spatial Cluser Analysis for Point Data: Location Quotients Verses Kernel Density. University Consortium of Geographic Information Science (UCGIS).

Magalhães, S. F. (2011, January 31). 20110151 Urban Upgrading in a Context of Violence: Physical space and security perception in the case of the Favela-Bairro in Rio de Janeiro.

Maia, C. (2011, January 31). 20110152 Urban Upgrading in a Context of Violence: Physical space and security perception in the case of the Favela-Bairro in Rio de Janeiro.

McCallum, D., \& Benjamin, S. (1985). Low-income urban housing in the third world: Broadening the economic perspective. Urban Studies, 22(4), 277-287.

Moser, C. O. N., \& McIlwaine, C. (2004). Encounters with violence in Latin America: Urban poor perceptions from Colombia and Guatemala. New York: Routledge.

Newman, O. (1972). Defensible space; Crime prevention through urban design. New York: Macmillan.

Pamuk, A., \& Cavallieri, P. F. A. (1998). Alleviating urban poverty in a global city: New trends in upgrading Rio-de-Janeiro's Favelas. Habitat International, 22(4), 449-462. Retrieved from https://doi.org/10.1016/S0197-3975(98)00022-8

Penglase, R. (2005). The shutdown of Rio de Janeiro The poetics of drug trafficker violence. Anthropology Today, 21 (5), 3-6.

Perlman, J. E. (2010). Favela: Four decades of living on the edge in Rio de Janeiro. Oxford; New York: Oxford University Press.

Phillips, T. (2010). iRio de Janeiro police occupy slums as city fights back against drug gangs. w. Te Guardian.

Pugh, C. (1994). Housing policy development in developing countriesThe World Bank and internationalization, 19721993. Cities Cities, 11(3), 159-180.

Pugh, C. (2000). Squatter settlements: Their sustainability, architectural contributions, and socio-economic roles. Cities, 17(5), 325-337.

Rabello de Castro, S. (2002). In holding their ground: Secure land tenure for the urban poor in developing countries. London; Sterling, Va.: Earthscan Publications.

Rangan, H. (2007). The Favela BAirro Program: Scaling up Urban development. In Collection. Monash University Research Publications. UNDP. Retrieved from http://arrow.monash.edu.au/hdl/1959.1/215287

Riley, E., Fiori, J., \& Ramirez, R. (2001). Favela Bairro and a new generation of housing programmes for the urban poor. Geoforum, 32(4), 521-531. https://doi.org/10.1016/S0016-7185(01)00016-1

Rodgers D. (2009). Slum wars of the 21st century: Gangs, mano dura and the new urban geography of conflict in Central America. Dev. Change Development and Change, 40(5), 949-976.

Rojas, E., Inter-American Development Bank., Cities Alliance., \& Taller "Programas de mejoramiento de barrios: análisis comparado de lecciones aprendidas y nuevos enfoques." (2010). Building cities: Neighborhood upgrading and urban quality of life. [Washington, D.C.]: Inter-American Development Bank; [Cambridge, Mass.]: Cities Alliance; David Rockefeller Center for Latin American Studies: [Distributed by Harvard University Press].

Roy, A. (2005). Urban Informality: Toward an Epistemology of Planning. Journal of the American Planning Association, 71(2), 147-158. https://doi.org/10.1080/01944360508976689

Samper Escobar, J. J. (2010). The politics of peace process in cities in conflict: The Medellin case as a best practice. Massachusetts Institute of Technology. Retrieved from http://hdl.handle.net/1721.1/59768

Samper, J. (jota). (2012). The role of urban upgrading in Latin America as warfare tool against the "slum wars". Critical Planning: The Journal of the UCLA Urban Planning Program, 19.

Satterthwaite, D. (2012). Upgrading Informal Settlements.

Schneider, R. (2006). Introduction: Crime prevention through environmental design (CPTED): Themes, theories, practice, and conflict. SAGE Urban Studies Abstracts, 34(3).

Strassmann, W. P. (1987). Home-based enterprises in cities of developing countries. Economic Development and Cultural Change, 36(1), 121-144.

Teddlie, C., \& Tashakkori, A. (2003). Major issues and controveries inthe use of mixed methods in the social and behvioral sciences. Handbook of Mixed Methods in Social \& Behavioral Research, 3-50.

United Nations Development Programme. (1992). Human development report 1992. New York: [Oxford University Press] for the United Nations Development Programme (UNDP).

United Nations Development Programme. (2009). Human development report 2009: Overcoming barriers: Human mobility and development. New York; Basingstoke: United Nations; Palgrave Macmillan. 
United Nations Human Settlements Programme. (2003). The challenge of slums: Global report on human settlements. London; Sterling, VA: Earthscan Publications.

Van Bronkhorst, B. (2003). A Resource Guide for Municipalities: Community-Based Crime and Violence Prevention in Latin America. World Bank, Washington, DC.

Vanderschueren, F. (1996). From violence to justice and security in cities. Environment and Urbanization, 8(1), 93-112.

Vanderschueren, F., Wegelin, E. A., \& Wekwete, K. (1996). Policy programme options for urban poverty reduction: A framework for action at the municipal level. Washington, D.C.: World Bank.

Weizman, E. (2006). The Architecture of Ariel Sharon. Third Text, 20(3-4), 337-353.

Weizman, E. (2007). Hollow land: Israel's architecture of occupation. Londoz. New York: Verso.

Wilson, J. Q., \& Kelling, G. L. (1982). Broken windows. In The American idea: the best of the Atlantic monthly: 150 years of writers and thinkers who shaped our history. New York: Atlantic Monthly.

Yin, R. K. (2009). Case study research: design and methods. SAGE.

Zaluar, A. (2000). Perverse Integration: Drug Trafficking and Youth in the "Favelas" of Rio de Janeiro. Jinteaffa Journal of International Affairs, 53(2), 653-671.

Zaluar, A., \& Alvito, M. (1998). Um século de favela. Rio de Janeiro, Brasil: Fundação Getulio Vargas Editora.

Zaluar, A. M. (2004). Integração perversa: pobreza e tráfico de drogas. Rio de Janeiro: Editora FGV. 